\author{
Andrzej Matczak \\ https://orcid.org/0000-0002-9509-5879 \\ University of Łódź \\ Faculty of Geographical Sciences \\ Institute of Urban Geography and Tourism Studies \\ andrzej.matczak@geo.uni.lodz.pl
}

\title{
CHANGES IN THE STRUCTURE OF THE TOURIST FUNCTION IN KUJAWY SPAS (BASED ON THE VOLUME AND STRUCTURE OF TOURIST TRAFFIC)
}

\begin{abstract}
The purpose of the paper is to identify changes in the structure of the tourism function in Kujawy spas which have led to their transformation into tourism and health resorts. The study was based on tourist traffic statistics referring to the period 2000-2017 and included defining the relationship between curative and other forms of tourist traffic. The author has used a wide range of statistical data, as well as information provided by surveys to determine and analyze the statistical indicators of tourist traffic pace, intensity and structure. The analysis reveals a significant transformation of the spas in Kujawy. This is confirmed by the indicators of curative and non-curative tourist traffic and by the reasons for visiting health resorts. The pace of changes in the tourism function in individual spas is varied. It is fastest in Ciechocinek, accelerating in Wieniec-Zdrój and slowest in Inowrocław. The changes occurring in the spas are causing their gradual transformation into tourism and health resorts.
\end{abstract}

Keywords: changes, structure of the tourist function, tourist traffic, Kujawy spas, Poland.

\section{INTRODUCTION}

Poland's return from a centrally planned to a market economy after 1989 has changed the tourism function in Polish spas, gradually increasing the range of services they provide. Traditional medicinal services have been systematically supplemented with recreation, entertainment, sport and other services. In this way, Polish spas are becoming multifunctional tourism resorts. This process has been indicated by many authors (Durydiwka, 2005; Groch, 1991; Jagusiewicz, 1998, 2006; Kowalczyk, 2001, 2005; Krasiński, 2004; Łęcka, 2005; Madeyski, 1997; Mika, 2005; Mika, Ptaszycka-Jackowska, 2007; Mościbroda, 2005; Ptaszycka-Jackowska, 1999; Rydz, 2005, 2012; Rzeńca, 1997; Szromek, 2010, 2012, 2018; Widawski, 2017 , etc.). Although it is similar to a process observed in other countries as well (Buzsik, Jónás-Berki, Köbli, Pálfi, 2015; Joppe, 2010; Kasagranda, Gurňák, 2017; Mainil, Eijgelaar, Klijs, Nawijn, Peeters, 2017; Vystoupul, Šauer, Bobková, 2017, etc.), it is difficult to verify in an academic way as such verification is often based on a description of the relations between the curative and the other tourism functions of spas. Many European health resorts (e.g. English resorts along the English Channel) continued to prosper on the market because, in addition to health, they developed other tourism functions as well (according to Butler's approach from 1980 - they renewed their tourism life cycle). Descriptive analyses of spas being transformed into multifunctional tourism centres have been usually based on the information available about the developing accommodation and, more rarely, on tourist volumes. Therefore, it seems appropriate to attempt to verify the value of information on tourism changes, as well as the motivations and activity of tourists visiting Polish spas, in order to determine how advanced the process of transformation is. The verification is based on a case study of the Kujawy health resorts.

Spas in Kujawy are relatively new. In all the destinations where they are located, it has led to socio-economic, cultural and spatial development. In Ciechocinek, it led to the creation of a town (1916), in Inowrocław to substantially enhance one's development (since 1875), and in Wieniec-Zdrój, it initiated and fostered the development of a residential district (since 1923). Thus, it may be assumed that the transformation of Kujawy health resorts into multifunctional tourism centres is currently at different stages for each.

Tourism is defined as a social phenomenon which involves physical, temporary movement from places of permanent residence to other locations which possess appropriate assets and tourism infrastructure (Mariot, 1983; Matczak, 1992; Ostrowski, 1972). It has been assumed that 
tourism (a collective concept) as a social phenomenon results from an interaction between deliberately acting human subjects (tourists). At the collective level, tourism defined in this way can be treated as a form of 'migration', i.e. temporary journeys away from place of permanent residence for tourism motivations. Aspects of tourism 'migrations' include scale, type, seasonality, spatial distribution, etc. (Kurek, 2007). At the level of an individual, it is defined by the tourist's motivation to travel and their behaviour.

\section{LITERATURE REVIEW}

The issues of the ongoing transformation of spas into multifunctional tourism resorts, identified on the basis of data regarding tourists and their motivations, indicate that it has become a fairly advanced process, widely acknowledged in the academic literature. When discussing the transformation of Mariánské Lázně (Marienbad) (in the Czech Republic) into a multifunctional tourist resort, Kowalczyk (2005) referred to the research made by Uzlik (2004), indicating that visiting both Mariánské Lázně and Karlovy Vary is associated with entertainment $(23.1 \%)$, participation in cultural life $(21.5 \%)$, recreation $(18.8 \%)$ and, finally, with caring for one's health (17.2\%). These findings show that those two destinations, until recently associated mostly with a purely curative function, are in fact multifunctional tourism resorts. Rettinger (2012) points to a similar process in Truskawiec where the proportion of spa patients has been decreasing and numbers arriving for recreational and tourist motivations has been increasing. When discussing the medicinal and tourism functions of spa resorts in Beskid Niski, Malarz (2012) ascertains that although their main function involves medical treatment, as a result of new investments in accommodation (hotels, guest-houses), and gastronomic, sports and recreation facilities, etc., the proportion of recreation- and tourism-oriented visits is growing. He remarks that visits combining health care and recreation motivations are becoming increasingly fashionable. Rajman \& Kwiatek-Sołtys (2011) write that although tourists arriving in Iwonicz-Zdrój (30,000 annually) outnumbered spa patients $(25,000)$, their proportion of accommodation was still less (1,500 to 818 places). After 1989, business tourism entered West-Pomeranian health resorts (Sawińska, 2012). In the opinion of Szajnowska-Wysocka (2011), Polish spas, following European trends, should turn into multifunctional centres of health care, tourism and recreation. She quotes statistics for the first decade of the $21^{\text {st }}$ century, which show that in 2007 the proportion taking up accommodation, compared to overall figures for Polish spa resorts, increased from $21.8 \%$ in 2002 to $28.4 \%$. That, however, made up only about one quarter of the overall total. Thus, the process of transformation of Polish spas was very advanced. Having the status of a health resort, has an impact on the use of accommodation at a spa which, consequently, substantially increases the overall number of people staying at collective accommodation facilities (ŚrodaMurawska, 2012). From the economic point of view, spas benefit from possessing a diversified tourist function, the spa being only a part of it. Mika \& PtaszyckaJackowska (2007) emphasize that current socio-economic and cultural changes contribute to the transformation of traditional health resorts into multifunctional tourism resorts. The diversification of the tourism function in spas as they develop, is then most often a result of changes in tourism itself and its wider context (Kowalczyk, 2005). The nature of these changes is easily noticeable in the nature of tourism itself, as well as in the motivations and behaviour of tourists visiting spa resorts.

Tourism in Kujawy health resorts has rarely been discussed as a separate issue, but rather as a part of wider research and in popular academic work. A lot of information regarding the scale, type and motivations noted among spa patients and tourists in different periods (especially in Ciechocinek and Inowrocław), can be found in guidebooks and geographical literature, as well as in individual works (Matczak, 2019). A number of academic articles are devoted solely to the study of spa patients' perceptions and how they see Inowrocław and Ciechocinek health resorts (Cieślewicz, Jankowiak, 2012; Grzeszczak, 2014; Szymańska, Grzelak-Kostulska, Hołowiecka, Michniewicz, 2005, etc.), but usually these are discussed as a part of larger works (Brudnicki, 2005; Matczak, 2012, 2013; Zajączkowski, Cegliński, 2018, etc.). In the MA theses written at the geography centres in Łódź, Bygoszcz and Torun, tourism issues (scale, type, range, purpose, tourist behaviour) always constitute a significant part (Matczak, 2019). Surveys regarding tourism, sponsored by the Kujawy-Pomeranian Tourism Organization, provide a large amount of market data (Anszperger, Radkiewicz, 2011; Brudnicki, Barczak, Nowicki, Markiewicz, 2016), including information on types of tourism, the purpose of tourists' visits to Ciechocinek and Inowrocław, etc.

\section{DATA AND RESEARCH METHODS}

The study of tourism in Kujawy spas was based on the following:

1. Statistical data provided by the Local Data Bank (LDB) at the Central Statistical Office (GUS), the figures published by the Statistical Office in Bydgoszcz, on the websites of relevant ministries, and the Kujawy-Pomeranian Province local governments and the health resorts included in the study;

2. The results of surveys conducted among tourists ordered by the Kujawy-Pomeranian Tourism Organi- 
zation, as well as some MA theses which the author had access to;

3. The author's own literature analysis and field observations.

Despite its wide range, the source material collected by the author has certain limitations which makes it difficult to conduct quantitative research on the scale and types of tourism, or tourists' motivations and behaviour in Kujawy health resorts. This is mainly due to the incompleteness of national, ${ }^{1}$ sector-specific and local statistics, as well as the lack of homogeneity of the survey materials (limited comparability and representativeness). The hypothesis formulated was verified in terms of changes in tourism (the users, accommodation provided, average length of stay, seasonality), mostly on the basis of data provided by the Central Statistical Office and information about types of tourists, the purpose of their visits, their behaviour in spa resorts and the areas from which they arrived (range), provided by surveys to which the author had access. The collected materials indicate general trends in the changes that are taking place in Kujawy health resorts.

\section{THE BASIS FOR TOURISM DEVELOPMENT IN KUJAWY HEALTH RESORTS²}

The scale and type of tourism, especially curative/medicinal tourism, observed in Kujawy spas, depends on the geographical location, tourism assets (mineral waters, climate, etc.), the presence of spa facilities (graduation towers, mineral water pump rooms, etc.), as well as conditions (accommodation, gastronomic facilities and the auxiliary infrastructure).

From the market/economic point of view, the geographical location of Kujawy spas is favourable. A particular advantage is their location at the centre of a 200kilometre radius. On the edge, the huge urban agglomerations of Warsaw, Łódź, Poznań and Gdańsk-Gdynia can be found, and inside, at a regional scale, a number of cities such as Bydgoszcz, Torun, Włocławek, etc. Provided that efficient road and rail transport is available, such a location gives Kujawy spas considerable potential as regards demand for medicinal and tourist services in general.

The spas in Kujawy are located within the existing settlement network, in a small town (Ciechocinek), a medium-sized town (Inowrocław) and in the direct neighbourhood of Włocławek (Wieniec-Zdrój). Location has a strong influence on the functioning and tourism attractiveness of spas. The infrastructure of a nearby urban centre provides a wide range of services, including basic ones and entertainment. The close proximity of an urban centre is a significant additional asset, as it makes the stay at the health resort much more pleasant. Numer- ous economic organisations and municipal institutions are involved in providing services to spa patients, organizing a variety of entertainment events, as well as making local historical, architectural, cultural and tourist heritage available. This significantly improves the attractiveness of spas and reduces the cost of investments in the spa itself.

The medicinal resources of Kujawy spas include saline mineral waters, mild climatic conditions, forest walking areas and spa greenery, as well as medicinal muds used for therapeutic baths, drinking mineral waters, aerosols produced from graduation towers (natural inhalations) and medicinal mud compresses. They make it possible to treat many chronic diseases and ailments such as orthopaedic traumas, rheumatism, heart diseases, hypertension, problems with respiratory and digestive system, diabetes, obesity, etc. (Lecznistwo uzdrowiskowe..., 2011).

The infrastructure which allowed more tourists to stay in Kujawy spas appeared in the 19'th century (Ciechocinek - 1836, Inowrocław - 1875) and the first half of the 20 ${ }^{\text {th }}$ (Wieniec-Zdrój - 1923). However, basic investments in accommodation facilities, especially sanatoria, were made in the times of social tourism (19451989).

In the early years following the change of the political system in 1989, new sanatoria were not built. Instead, investment was spent on the modernization of the existing accommodation, health facilities and the auxiliary infrastructure (e.g. modernizing the graduation towers in Ciechocinek, building a new one in Inowrocław, modernization of Wieniec-Zdrój in 2003-6). Some money was invested in tidying and developing spa parks, walks, etc. The overall appearance of the spa zones also improved. New private owners of spa infrastructure invested in recreating and modernizing the facilities they had taken over (e.g. in Ciechocinek, those that used to belong to the Workers' Holidays Fund). New investments were made in hotel accommodation (hotels, guest houses, villas, etc.), guest rooms and private lodgings. After 1989, a large number of state-owned accommodation facilities were privatised, particularly hotels which had formerly been the property of factories and the Workers' Holidays Fund. Privatisation occurred in practically the whole of Wieniec-Zdrój and was managed by limited liability companies, private enterprises, foundations, public organizations, trade union federations and individual private owners.

The return to the market economy after 1989 caused temporary problems in the functioning of Kujawy spas. The capacity of registered accommodation in spa and tourist-recreational facilities decreased by two thirds. It was not until 2000 that Kujawy spas recorded a substantial increase in the capacity of accommodation and some changes in its pattern. In 2000, the capacity of registered accommodation in tourist-recreational and spa facilities 
in Ciechocinek and Inowrocław was similar $(44.5 \%$ and $45.2 \%$, respectively), while in Wieniec-Zdrój it was only one tenth of the capacity recorded in the other two spas. In 2018, together they offered 9,200 beds which made up $28.4 \%$ of all the accommodation available in KujawyPomeranian Province and over one third of the number of beds offered throughout the year. Three quarters of registered accommodation belonged to medicinal facilities, with the largest number of beds available in Ciechocinek $(4,200)$, and smaller numbers in Inowrocław $(1,800)$ and Wieniec-Zdrój $(1,100)$. The capacity of other registered accommodation was largest in Ciechocinek $(1,700$ beds $-28 \%)$, smaller in Inowrocław $(300-14.3 \%)$ and especially in Wieniec-Zdrój (50 beds - 4.3\%). In all Kujawy spas, there were also a lot of accommodation facilities unregistered in official statistics or by other state institutions. It is difficult to estimate their capacity (e.g. in Ciechocinek alone, it may reach several thousand beds). New investments, as well as those aimed at recreating and modernising the old infrastructure, were focused primarily on facilities which could function all year round; the proportion of the latter was systematically increasing, virtually eliminating seasonal facilities.

Kujawy spas are well equipped in gastronomic and auxiliary infrastructure. The gastronomic infrastructure included food facilities situated in sanatoria, in and on the edges of spa parks, as well as in other parts of the health resorts. Spa patients valued gastronomic facilities located directly in the sanatoria (canteens) the most. All large sanatoria had their own catering infrastructure. It is estimated that in Ciechocinek, in the summer season, this included over 7,100 places. In the spa zone of Inowrocław, it was about 1,000 and in Wieniec-Zdrój fewer. Gastronomic facilities varied and were prepared to satisfy consumers' differing needs. Facilities such as restaurants, cafes and some canteens were also prepared to organize dance evenings, get-to-know-you evenings (mixers) and other events of this kind. Tourists could also take advantage of a wide variety of gastronomic establishments situated in other parts of Inowrocław and Ciechocinek.

Kujawy spas can boast of a well-developed supplementary infrastructure. This includes a wide range of amenities supporting treatment and recreation such as graduation towers, indoor saline swimming pools, tennis courts, mini-golf, bowling alleys, board game rooms, billiards, table tennis, library activities, etc., available at both spa and tourism facilities. In Ciechocinek and Inowrocław, residents as well as spa patients and tourists can take advantage of stadiums, sports halls, sports and recreation centres, bike rentals, excursion organization centres, cinemas, outdoor theatres, band stands and a wide range of urban services. Drivers can use several parking lots. The supporting infrastructure plays a major part in organizing events such as social meetings, dance parties, festivals and concerts, meetings with the folklore of Kujawy and Dobrzyńska Land, and many others. Some sanatoria offer additional services such as sun-beds, beauty parlours, saunas, community rooms, Tibetan hot stone therapy, inhalations in a salt grotto, etc., as well as organizing lectures promoting healthy lifestyles given by qualified psychologists and doctors competent as regards the causes of the diseases of civilization. Spa facilities offered 58 conference rooms with 4,500 seats, equipped with modern audio-visual devices (sound systems, microphones, projectors, screens, computers, etc.). The largest could be found in Ciechocinek, followed by Inowrocław and Wieniec-Zdrój.

The scale and type of supply in Kujawy health resorts, ensures an attractive stay not only to spa patients but also participants of many other forms of tourism.

\section{STUDY RESULTS}

Analysis of the dynamics of both forms of tourism (curative and non-curative) allowed the author to define the relationship between them which was fundamental to establishing the changes occurring in the tourism function in Kujawy spas. Similar information was provided by the results of a survey concerning the demographic structure, motivations for visits, behaviour and origins of the visitors to these health resorts. Jointly, the findings show how advanced the changes in tourism function have become.

\subsection{THE SCALE AND TYPES OF TOURISM IN REGISTERED ACCOMMODATION FACILITIES}

Tourists stay at different types of accommodation. Until the end of 2014, the only source of information regarding the number of guests and overnight stays had been the Local Data Bank at the Central Statistical Office. The scale and types of tourism were based on this data. Spa patients are mostly accommodated at spa facilities and the registers kept there should be regarded as reliable and complete. However, a number (usually small) who use accommodation at spa facilities are not spa patients. On the other hand, a number of spa patients use accommodation at tourist-recreational facilities (hotels, holiday centres, private lodgings, etc.). Registration at these facilities (except categorized hotels) is not complete, therefore the number of users and overnight stays is not fully credible and allows only a general description of current trends. After 2014, it became possible to provide information about the number of users and overnight stays in individual powiats. Confirming such numbers in individual health resorts requires collecting and comparing numerous statistical reports and using personal estimates. Thus, establishing the proportion of spa patients 
to the number of other types of tourist is limited to just indicating a general trend.

People using registered accommodation. At the beginning of the $21^{\text {st }}$ century, the number of guests using registered accommodation facilities in Kujawy spas visibly increased. This trend was maintained for nearly two decades (Table 1). In 1988, accommodation facilities in Kujawy spas were used by 56,500 guests, in 2014 - nearly 160,000 , and towards the end of 2018 - about 150,000 (Urząd Statystyczny w Bydgoszczy, 2019). These spas recorded a significant and systematically growing proportion of guests using registered accommodation facilities in Kujawy-Pomeranian Province. In 1998-2018, this percentage increased from $8.1 \%$ to $11.6 \%$. At the beginning of the $21^{\text {st }}$ century, most guests staying at registered accommodation facilities were at Inowrocław $(36,800)$, followed by Ciechocinek $(31,700)$ and WieniecZdrój $(4,300)$. In the following years, the number of guests using registered accommodation increased in all three health resorts, mainly due to the systematically recovered capacity of spa facilities and their growing usability. However, the rate of increase varied: it was highest in Ciechocinek (the number of users increased to about 112,000 in 2014) and Wieniec-Zdrój (6,800), and lowest in Inowrocław $(40,800)$. In 1998, more guests arriving in Kujawy spas stayed at tourist-recreational (56.7\%) and not spa facilities (43.3\%). However, in 2000, the percentage of spa facilities had increased to $60.2 \%$ and it grew in the years that followed to reach $75.7 \%$ in 2014 . The proportion of guests using spa facilities to those using other registered accommodation was different in individual spas. In 2000, the smallest percentage of spa patients was recorded in Inowrocław (52\%) followed by Ciechocinek (65\%) and the highest in Wieniec-Zdrój (93\%). In 2014, Ciechocinek and Wieniec-Zdrój maintained the same proportions, while in Inowrocław, it had risen to $86 \%$. After 2015, a large spa accommodation facility was opened leading to a five-fold increase in the number of spa patients using accommodation in this health resort. As a result, in 2018, the proportion of Ciechocinek and Inowrocław decreased (to two thirds and one quarter, respectively) and that of Wieniec-Zdrój increased (to nearly one tenth) in the overall number of accommodation users.

In 2000-2018, accommodation in Kujawy health resorts was used by only a small number of foreigners (2,200-8,200 annually). Despite the increase in the number of foreign tourists, their percentage in the overall number of accommodation users in Kujawy spas was low and varied from around $3.1 \%$ in 2000 to about $3.3 \%$ in 2018. Initially, the majority of foreigners were recorded in Inowrocław (about three quarters), mostly staying at tourist-recreational facilities. With time, the number of foreign visitors accommodated in Inowrocław decreased and significantly increased in Ciechocinek. In 2017, 57.4\% of the foreigners using accommodation in Kujawy health resorts stayed in Ciechocinek, 39\% in Inowrocław, and $3.6 \%$ in Wieniec-Zdrój.

Table 1. Accommodation in Kujawy health resorts: 2000-2017

\begin{tabular}{|c|c|c|c|c|c|c|c|c|c|c|}
\hline \multirow{3}{*}{ Year } & \multicolumn{10}{|c|}{ Number of guests using accommodation facilities (in thousands) } \\
\hline & \multicolumn{2}{|c|}{$\begin{array}{c}\text { Kujawy-Pomeranian } \\
\text { Province }\end{array}$} & \multicolumn{2}{|c|}{$\begin{array}{l}\text { Total for Kujawy } \\
\text { health resorts }\end{array}$} & \multicolumn{2}{|c|}{ Ciechocinek } & \multicolumn{2}{|c|}{ Inowrocław } & \multicolumn{2}{|c|}{ Wieniec-Zdrój } \\
\hline & total & foreign & total & foreign & total & foreign & total & foreign & total & foreign \\
\hline \multicolumn{11}{|c|}{ Total for tourist-recreational and spa facilities } \\
\hline 2000 & 576.3 & 66.9 & 72.8 & 2.3 & 31.7 & 0.5 & 36.8 & 1.7 & 4.3 & 0.1 \\
\hline 2005 & 662.7 & 86.7 & 100.8 & 2.9 & 58.9 & 1.5 & 37.1 & 1.4 & 4.8 & 0 \\
\hline 2010 & 793.9 & 79.5 & 129.4 & 2.7 & 88.1 & 1.5 & 35.8 & 1.2 & 5.5 & 0 \\
\hline 2014 & 929.4 & 89.9 & 159.4 & 2.4 & 111.8 & 1.2 & 40.8 & 0.7 & 6.8 & 0 \\
\hline $2017^{\mathrm{a}}$ & 1294.0 & 120.7 & 246.7 & 8.2 & 166.4 & 4.7 & 61.0 & 3.2 & 19.3 & 0.3 \\
\hline \multicolumn{11}{|c|}{ Tourist-recreational facilities } \\
\hline 2000 & 529.8 & 66.6 & 26.3 & 2.0 & 11.1 & 0.4 & 17.6 & 1.6 & 0.3 & 0 \\
\hline 2005 & 596.3 & 86.4 & 34.4 & 2.6 & 26.0 & 1.4 & 8.0 & 1.2 & 0.4 & 0 \\
\hline 2010 & 700.5 & 78.4 & 36.0 & 1.6 & 26.6 & 0.5 & 8.7 & 1.0 & 0.7 & 0 \\
\hline 2014 & 807.2 & 88.7 & 37.2 & 1.2 & 30.0 & 0.1 & 6.1 & 0.6 & 1.1 & 0 \\
\hline $2017^{a}$ & 1158.0 & 118.9 & 110.7 & 6.3 & 81.8 & n.d. & 25.7 & n.d. & 3.3 & n.d. \\
\hline \multicolumn{11}{|c|}{ Spa facilities } \\
\hline 2000 & 46.5 & 0.3 & 46.5 & 0.3 & 20.6 & 0.1 & 19.2 & 0.1 & 4.0 & 0.1 \\
\hline 2005 & 66.4 & 0.3 & 66.4 & 0.3 & 32.9 & 0.1 & 29.1 & 0.2 & 4.4 & 0 \\
\hline 2010 & 93.4 & 1.1 & 93.4 & 1.1 & 61.5 & 1.0 & 27.1 & 0.2 & 4.8 & 0 \\
\hline 2014 & 122.2 & 1.2 & 122.2 & 1.2 & 81.8 & 1.1 & 34.7 & 0.1 & 5.7 & 0 \\
\hline $2017^{\mathrm{a}}$ & 136.0 & 1.8 & 136.0 & 1.9 & 84.6 & n.d. & 35.3 & n.d. & 16.0 & n.d. \\
\hline
\end{tabular}

${ }^{a}$ Data for powiats in which the spa resorts included in the study are located.

Source: based on LDB at the Central Statistical Office data, Turystyka w latach 2001-2018 (2019), Urząd Statystyczny w Bydgoszczv (2019). 
Overnight stays. A different picture of the changes in tourism in Kujawy spas in the 21 $1^{\text {st }}$ century emerges from the number of overnight stays (Table 2, Figure 1). In Kujawy-Pomeranian Province, in 2000-2017, there was a significant increase in the number of overnight stays by guests at accommodation facilities, from 2.3 to 4.3 million. Nearly the whole increase occurred in Kujawy spas where the number of overnight stays rose from 0.9 to 2.3 million, mainly in Ciechocinek (from 0.36 to 1.44 million). The increase was found mostly in spa facilities (from 0.8 to 2.0 million), particularly in Ciechocinek (from 0.32 to 1.2 million). This caused a significant increase in the share of overnight stays in Kujawy spas and in overnight stays for the whole region (from $38.2 \%$ to $54 \%$ ). The most substantial increase occurred in spa facilities where the proportion of overnight stays in Kujawy-Pomeranian Province went up from $34.8 \%$ to $48.1 \%$. Ciechocinek played a particularly important part in this increase, as its proportion of overnight stays in the region rose from $15.8 \%$ to $33.8 \%$ (and the proportion for spa facilities from $14.1 \%$ to $28.6 \%$ ). Ciechocinek became the most important spa centre in Kujawy-Pomeranian Province despite the fact that in 2000 Inowrocław health resort had provided about 100,000 more overnight stays.

Despite an increase from 8,000 to nearly 16,000, the number of foreigners' overnight stays in Kujawy spas still indicates that they are not real international resorts. The percentage of Kujawy spas in the number of nights spent in the region by foreigners was marginal.

Average length of stay. The average length of stay in health resorts shows the level their transformation process has reached. The longer the average stay, the more significant the curative function, and vice versa: shorter stays indicate the growing role of non-curative functions. The influence of spas is visible in the average number of tourists' overnight stays at accommodation facilities in the whole Kujawy-Pomeranian Province (from 4 nights in 2000 to 3.3 nights in 2017). The average number of overnight stays per guest in Kujawy spas varied, depending on the kind of accommodation that was used. In 2000-2017, a guest spent, on average, 2.6 nights in touristrecreational facilities (this value varied between 2.3 and 3 nights). This was a much higher value than the average for the whole Kujawy-Pomeranian Province for the same type of accommodation and in the same period. The latter dropped from 2.9 to 1.8 nights. Long stays in health resorts occurred first of all in spa facilities where the guests usually spent 2-3 weeks. Over the period under study, the average number of overnight stays by individual guests at spa facilities tended to fall, going from 17.1 in 2000 to 15.1 in 2017. This was most visible in WieniecZdrój (a drop from 21.8 to 16.4 nights) and Inowrocław (from 20.1 to 15.2 nights), while in Ciechocinek, the decrease was considerably smaller (from 15.7 to 14.4 nights).

Foreigners' stays in Kujawy health resorts were generally shorter than those of domestic guests (at tourist- recreational facilities - 2.3-3.0 nights; at spa facilities - 10.013.3 nights).

Seasonality. Fluctuation in the number of tourists during the year is defined as seasonality. In tourism, this occurs with varying intensity. It is a global phenomenon which depends on natural conditions, the form of tourism, the place where it occurs, traditions of tourist trips, etc. (Butler, 1994). The analysis of seasonality in the relation between medicinal and other forms of tourism in spas shows how advanced the process of their transformation
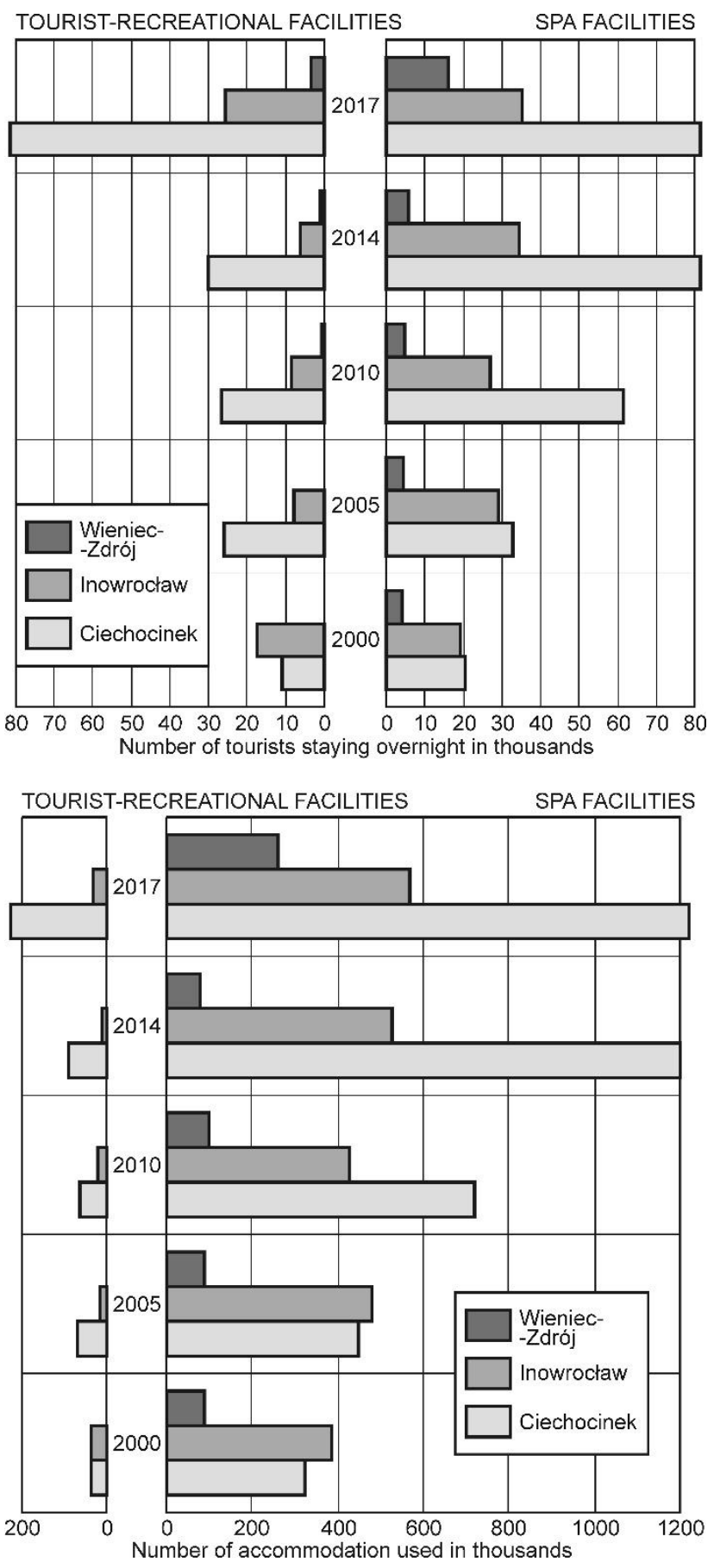

Figure 1. Tourists staying overnight and the accommodation used in Kujawy health resorts: 2000-2017 Source: author 
Table 2. Number of overnight stays in Kujawy spas: 2000-2017

\begin{tabular}{|c|c|c|c|c|c|c|c|c|c|c|}
\hline \multirow{3}{*}{ Year } & \multicolumn{10}{|c|}{ Number of overnight stays (in thousands) } \\
\hline & \multicolumn{2}{|c|}{$\begin{array}{c}\text { Kujawy-Pomeranian } \\
\text { Province }\end{array}$} & \multicolumn{2}{|c|}{$\begin{array}{l}\text { total for Kujawy } \\
\text { health resorts }\end{array}$} & \multicolumn{2}{|c|}{ Ciechocinek } & \multicolumn{2}{|c|}{ Inowrocław } & \multicolumn{2}{|c|}{ Wieniec-Zdrój } \\
\hline & total & foreign & total & foreign & total & foreign & total & foreign & total & foreign \\
\hline \multicolumn{11}{|c|}{ Total for tourist-recreational and spa facilities } \\
\hline 2000 & 2286.7 & 125.0 & 873.9 & 8.1 & 361.4 & 3.0 & 421.7 & 5.0 & 90.8 & 0.1 \\
\hline 2005 & 2395.4 & 159.0 & 1107.2 & 11.9 & 518.6 & 6.9 & 496.4 & 5.0 & 92.2 & 0.0 \\
\hline 2010 & 2668.7 & 176.9 & 1339.6 & 18.5 & 785.7 & 13.8 & 449.0 & 4.6 & 104.9 & 0.0 \\
\hline 2014 & 3290.6 & 190.1 & 1906.1 & 15.5 & 1288.4 & 12.6 & 538.0 & 2.9 & 79.7 & 0.0 \\
\hline $2017^{a}$ & 4271.4 & 290.6 & 2313.2 & 28.8 & 1443.0 & 20.0 & 600.4 & 7.5 & 269.8 & 1.3 \\
\hline \multicolumn{11}{|c|}{ Tourist-recreational facilities } \\
\hline 2000 & 1491.4 & 121.6 & 78.6 & 4.7 & 38.7 & 0.8 & 36.4 & 3.9 & 3.5 & 0.0 \\
\hline 2005 & 1377.3 & 155.0 & 89.1 & 7.9 & 69.5 & 5.1 & 17.8 & 2.8 & 1.8 & 0.0 \\
\hline 2010 & 1416.9 & 163.7 & 87.8 & 5.3 & 64.5 & 2.3 & 18.9 & 2.9 & 4.4 & 0.0 \\
\hline 2014 & 1486.0 & 178.1 & 101.5 & 3.5 & 88.2 & 1.9 & 11.9 & 1.6 & 1.4 & 0.0 \\
\hline $2017^{a}$ & 2216.6 & 274.9 & 258.4 & 13.1 & 221.8 & 9.1 & 29.3 & 3.4 & 7.3 & 0.6 \\
\hline \multicolumn{11}{|c|}{ Spa facilities } \\
\hline 2000 & 795.3 & 3.4 & 795.3 & 3.4 & 322.7 & 2.2 & 385.3 & 1.1 & 87.3 & 0.1 \\
\hline 2005 & 1018.1 & 4.0 & 1018.1 & 4.0 & 449.1 & 1.8 & 478.6 & 2.2 & 90.4 & 0.0 \\
\hline 2010 & 1251.8 & 13.2 & 1251.8 & 13.2 & 721.2 & 11.5 & 430.1 & 1.7 & 100.5 & 0.0 \\
\hline 2014 & 1804.6 & 12.0 & 1804.6 & 12.0 & 1200.2 & 10.7 & 526.1 & 1.3 & 78.3 & 0.0 \\
\hline $2017^{a}$ & 2054.8 & 15.7 & 2054.8 & 15.7 & 1221.2 & 10.9 & 571.1 & 4.1 & 262.5 & 0.7 \\
\hline
\end{tabular}

${ }^{a}$ Data for powiats in which the spa resorts included in the study are located.

Source: based on LDB at the Central Statistical Office data, Turystyka w latach 2001-2018 (2019), Urząd Statystyczny w Bydgoszczy (2019).

is. In Polish conditions, tourism shows clear seasonality, culminating during the summer holiday season (July and August). Curative tourism is distributed relatively evenly throughout the year. Thus, distinctive seasonality is in other types of tourism relative to therapeutic stays. The reverse, a lack of distinctive seasonality points to the predominance of therapeutic stays.

The data obtained from the Central Statistical Office presents the phenomenon of seasonality (accommodation users, number of overnight stays) by province and accommodation type. This makes it impossible to analyse seasonality in individual spas. Seasonality analysis is possible at the level of all Kujawy spas, with respect to accommodation users and overnight stays at spa facilities. In contrast, seasonality analysis with respect to users of other accommodation is possible at the level of Kujawy-Pomeranian Province (Table 3). A comparison of the seasonality of therapeutic stays with other forms of tourism, based on GUS data, indicates only general trends. At spa facilities (2000-2017), the curative season lasted from April to November (in those months, the seasonality index was over 100). In the other accommodation facilities in Kujawy-Pomeranian Province, the tourist season was shorter lasting from May to September inclusively (a seasonality index over 100). The insignificant seasonal variations in tourist volumes at spa facilities had a positive effect of decreasing the seasonality in the other accommodation facilities in the province.
Acquiring information about tourism seasonality directly at individual accommodation facilities in $\mathrm{Ku}-$ jawy spas turned out to be very difficult. It was available only with regard to several facilities in Ciechocinek for the period of 2001-2004 (Jędrzejewska, 2002; Świder, 2005). Based on the information provided by the Central Statistical Office, there is a significant similarity between the seasonality index of accommodation users in Ciechocinek during the year, and the seasonality index calculated for the whole province (Table 3). In Ciechocinek the season lasted from May to October (a seasonality index over 100) though it was more evenly distributed during the year in spa facilities than in other types of accommodation. The presence of spa patients decreased the seasonality of the accommodation infrastructure of Ciechocinek.

Changes in development indices for the tourism function: 2000-2017. The tourism function indices shown in Table 4, based on the intensity of tourism in Kujawy spas, were calculated in relation to their area (Ciechocinek $-15.6 \mathrm{~km}^{2}$, Inowrocław $-30.4 \mathrm{~km}^{2}$, Wieniec-Zalesie solectwo including the Wieniec-Zdrój district -16.4 km²) and the number of residents living within the administrative borders of Ciechocinek (in 2000 - 11,300 and in $2017-10,600)$, Inowrocław $(79,400$ and 73,600, respectively) as well as Wieniec-Zalesie solectwo (500). Taking GUS inaccuracies into account, the values of these indices should be interpreted in the context of the emerging trend. 
Table 3. Tourism seasonality indices in Kujawy-Pomeranian Province: 2000-2017

\begin{tabular}{|c|c|c|c|c|c|c|}
\hline \multirow{3}{*}{ Months } & \multicolumn{4}{|c|}{ Kujawy-Pomeranian Province (2000-2017) } & \multirow{2}{*}{\multicolumn{2}{|c|}{$\begin{array}{c}\text { Ciechocinek (2001-2004) } \\
\text { accommodation users }\end{array}$}} \\
\hline & \multicolumn{2}{|c|}{ accommodation users } & \multicolumn{2}{|c|}{ overnight stays } & & \\
\hline & in spa facilities & $\begin{array}{l}\text { in other accom- } \\
\text { modation }\end{array}$ & in spa facilities & $\begin{array}{l}\text { in other accom- } \\
\text { modation }\end{array}$ & in spa facilities & $\begin{array}{l}\text { in other accom- } \\
\text { modation }\end{array}$ \\
\hline Jan & 95.7 & 61.3 & 76.9 & 52.1 & 82.1 & 28.5 \\
\hline Feb & 85.6 & 63.0 & 88.0 & 54.1 & 83.4 & 63.2 \\
\hline March & 98.1 & 72.0 & 101.9 & 58.6 & 83.4 & 43.7 \\
\hline April & 102.7 & 79.5 & 98.6 & 67.0 & 95.4 & 65.3 \\
\hline May & 101.0 & 124.5 & 106.2 & 104.9 & 100.7 & 118.7 \\
\hline June & 111.9 & 136.9 & 104.4 & 125.8 & 109.9 & 149.3 \\
\hline July & 107.3 & 143.3 & 111.1 & 206.8 & 129.8 & 174.3 \\
\hline August & 109.4 & 143.1 & 111.6 & 194.5 & 131.1 & 191.0 \\
\hline Sep & 100.7 & 121.5 & 106.3 & 108.7 & 117.9 & 139.6 \\
\hline Oct & 110.7 & 99.7 & 108.8 & 88.0 & 100.7 & 116.7 \\
\hline Nov & 104.1 & 86.1 & 102.3 & 79.6 & 87.4 & 59.7 \\
\hline Dec & 71.2 & 69.2 & 83.9 & 59.8 & 78.1 & 50.0 \\
\hline
\end{tabular}

Source: calculations based on Turystyka w latach 2001-2018 (2019), Jędrzejewska (2002), Świder (2005). For Kujawy-Pomeranian Province - the mean seasonality index in 2000-2017, for Ciechocinek - 2001-2002.

Table 4. Changes in development indices for the tourism function in Kujawy spas, in 2000-2017, based on the Schneider index (the number of guests $\times 100 /$ number of residents), Charvat index (the number of person-nights $\times 100 /$ number of residents), accommodation users per $\mathrm{km}^{2}$ (users/area in $\mathrm{km}^{2}$ ), overnight stays per $\mathrm{km}^{2}$ (overnight stays/area in $\mathrm{km}^{2}$ )

\begin{tabular}{|c|c|c|c|c|c|c|}
\hline \multirow{2}{*}{ Health resort } & \multicolumn{2}{|c|}{ Total } & \multicolumn{2}{|c|}{ Curative function } & \multicolumn{2}{|c|}{ Other tourist functions } \\
\hline & 2000 & 2017 & 2000 & 2017 & 2000 & 2017 \\
\hline \multicolumn{7}{|c|}{ Schneider index } \\
\hline Ciechocinek & 280.5 & $1,569.8$ & 182.3 & 798.1 & 98.2 & 771.7 \\
\hline Inowrocław & 46.3 & 82.9 & 24.2 & 48.0 & 22.2 & 34.9 \\
\hline Wieniec-Zdrój & $1,004.7$ & $3,468.7$ & 934.6 & $3,738.3$ & 70.1 & 660.0 \\
\hline \multicolumn{7}{|c|}{ Charvat index } \\
\hline Ciechocinek & 3198.2 & $13,613.2$ & $2,855.7$ & $11,520.7$ & 342.5 & $2,092.4$ \\
\hline Inowrocław & 531.1 & 815.8 & 485.3 & 775.9 & 45.8 & 39.8 \\
\hline Wieniec-Zdrój & $21,214.9$ & $63,037.4$ & $20,397.2$ & $61,331.8$ & 817.7 & $1,705.6$ \\
\hline \multicolumn{7}{|c|}{ Accommodation user index } \\
\hline Ciechocinek & $2,032.0$ & $10,666.7$ & $1,320.5$ & $5,423.1$ & 711.5 & $5,243.6$ \\
\hline Inowrocław & $1,210.5$ & $2,006.6$ & 631.6 & $1,161.2$ & 578.9 & 845.4 \\
\hline Wieniec-Zdrój & 262.2 & $1,176.8$ & 243.9 & 975.6 & 18.3 & 201.2 \\
\hline \multicolumn{7}{|c|}{ Overnight stay index } \\
\hline Ciechocinek & $23,166.7$ & $92,500.0$ & $20,685.9$ & $78,282.0$ & $2,480.8$ & $14,217.9$ \\
\hline Inowrocław & $13,871.7$ & $19,750.0$ & $12,674.3$ & $18,786.2$ & $1,197.4$ & 963.8 \\
\hline Wieniec-Zdrój & $5,536.6$ & $16,451.2$ & $5,323.2$ & $16,006.1$ & 213.4 & 445.1 \\
\hline
\end{tabular}

Source: based on information provided by the Local Data Bank at the Central Statistical Office, Turystyka w latach 2001-2018 (2019), Urząd Statystyczny w Bydgoszczy (2019), Działalność lecznicza... (2018).

The indices that were calculated generally show that the tourism function in Kujawy spas had developed. There are differences in this respect between individual spas. The growth of the tourism function was most significant in Ciechocinek (a 4 - 5.6-fold increase) and WieniecZdrój (a 3 - 4.5-fold increase) - according to the indices they both had a fully developed tourism function. In Inowrocław, the index values changed rather insignificantly (a 1.4 - 1.8-fold increase). In Ciechocinek, despite the dynamic development of the curative function (3.8 - 4.4-fold increase), the non-curative tourist function was developing faster (a 5.7 - 7.9-fold increase). In both cases, the index values indicate a fully developed curative as well as non-curative tourism function. In Wieniec-Zdrój, growth in the curative function was also high (a 3 - 4-fold increase). As regards the non-curative tourist function, the indices rose significantly in relation to the number of users (9.4 - 11-fold increase). In relation to the number of overnight stays, the index values rose only slightly (a 2.1-fold increase). This means a larger number of visits but shorter stays. The curative and non-curative indices calculated for Wieniec-Zdrój clearly show that both functions are well developed there, with the noncurative function growing faster. In Inowrocław, the 
growth of the curative function was slow (a 1.6 - 2-fold increase), but still faster than that of the non-curative function. The indices referring to the number of users showed a small increase (1.5 - 1.6-fold), while those referring to the number of overnight stays showed a decline (by $10-20 \%$ ). Inowrocław was at an early stage of the development of both curative and non-curative functions. The faster growth of the non-curative function indices in Ciechocinek and Wieniec-Zdrój is evidence of their transformation into tourism and health resorts. Considering tourism function growth indices in Inowrocław, this process has not occurred.

\subsection{THE TYPE AND ACTIVITY OF SPA PATIENTS AND OTHER TOURISTS BASED ON SURVEYS}

The results of surveys conducted in Kujawy spas (Anszparger, Radkiewicz, 2011; Brudnicki, Barczak, Nowicki, Markiewicz, 2016; Caban, 2017; Glaza, 2008; Skonieczna, 2011, etc.) are difficult to compare. They were based partly on different sets of questions and conducted at different times, and on samples of different sizes (from ca. 200 to 735 respondents). They show that visitors to Kujawy spas were mostly the elderly (Table 5) with over half of them aged over 50. Nearly two thirds were women. A significant majority were old-age-pensioners and retired (over $50 \%$ ). Nearly half of the respondents arrived alone, and others with their families and/or friends. Guests at Kujawy spas were well educated, nearly half of them with secondary or further education and one third with university education. To travel to Kujawy spas, respondents mostly used road transport, over two thirds of them travelled by private car, and slightly below $15 \%$ by bus/minibus or coach. The rail connections between Inowrocław and numerous areas of Poland encouraged about one fifth of respondents to travel by train but in the other Kujawy spas this particular means of transport has clearly lost popularity in recent years. The spa in Ciechocinek largely functioned based on regular visitors. In the survey, only about one third of respondents said it was their first visit. The other two thirds had already visited spas several (2-4) or many times before (5 or more). As for Wieniec-Zdrój, over four fifths of respondents were visiting it for the first time and this spa does not have a large number of regular guests. The respondents expressed positive opinions about their stays in Kujawy spas. They believed that the greatest assets included the graduation towers in Ciechocinek and Inowrocław, a wide range of treatments and spa parks in all three health resorts. Most respondents claimed that Kujawy spas did not have major disadvantages but a lot of assets. Above all they pointed to a good and friendly atmosphere as well as the cleanliness and level of security at the health resorts, good access, a wide range of cultural and entertainment events, as well as historical monuments and attractions in the spas themselves and in nearby destinations.

Kujawy spas were visited primarily for health and recreational reasons in similar proportions in Ciechocinek, mostly for health reasons in Inowrocław and especially so in Wieniec-Zdrój (Table 5). Ciechocinek was indicated as a medicinal destination by $37.9 \%$ of the respondents, Inowrocław by $48.4 \%$ and Wieniec-Zdrój by $66.8 \%$. A recreational motivation in connection with Ciechocinek was mentioned by $36.7 \%$, Inowrocław by $34.7 \%$ and Wieniec-Zdrój by only $18 \%$. Other motivations for visits quoted (tourism, visiting relatives, business, etc.) were declared by less than $15 \%$ of the respondents.

People visiting Kujawy spas for curative and noncurative reasons formed two separate groups, differing with respect to their demographic and socio-economic status, the purpose of the visit and their activity in the spas. Skonieczna (2011) in her MA thesis described only non-curative tourism participants in Ciechocinek ( $\mathrm{n}=196$ respondents). The research showed that the visitors were visibly younger (the age median -42 years), two thirds of them working (among the non-working group, 13.3\% were OAPs and retired people), with university (49\%) and secondary (44.9\%) education. Two thirds of them travelled by their own car, with family (28.6\%), partner (30.6\%), friends $(20.4 \%)$ or colleagues $(14.3 \%)$. They stayed for a short time: without an overnight stay $(9.2 \%)$ and with $1-3$ overnight stays $(45.9 \%)$. Longer stays were declared by $44.9 \%$ of respondents. Their stay in Ciechocinek had many motivations with reasons related to recreation $(79.6 \%)$, entertainment (58.2\%), cognition (41.8\%), disease prevention $(22.6 \%)$, business $(15.5 \%)$, gastronomy $(10.2 \%)$ and visiting relatives and friends $(9.2 \%)$. They mostly used accommodation in guest rooms $(22.4 \%)$ and private lodgings (10.2\%), hotels (18.4\%), villas (16.3\%) and pensions $(11.2 \%)$, as well as at holiday recreation facilities $(9.2 \%)$ and training centres $(2 \%)$. They ate in restaurants away from their place of accommodation $(88.8 \%)$ and prepared meals themselves where they were staying (50\%). They also used small-scale catering services $(26.5 \%)$. Only $34.5 \%$ of the respondents used the restaurants at their accommodation facilities. The forms of accommodation and catering that the tourists are provided with has economic significance for the inhabitants of Ciechocinek. Tourists staying in Ciechocinek also used preventive treatments offered outside the sanatoria (31.4\%), at the sanatoria $(27.5 \%)$, and recreation facilities (e.g. the swimming pool) outside their accommodation. They also took regular walks near the saline graduation towers $(93.9 \%)$.

The respondents' (spa patients' and tourists') most frequent activity included strolling in spa parks and other parts of the health resorts (especially service centres), going to cafes and restaurants, to dancing parties, and participating in cultural events organized locally. The reasons why the guests travelled to spas largely determined the 
Table 5. Description of respondents and their stay in Kujawy spas (\%)

\begin{tabular}{|c|c|c|c|}
\hline The characteristics of respondents and their stay & $\begin{array}{c}\text { Ciechocinek } \\
(\mathrm{n}=735)\end{array}$ & $\begin{array}{c}\text { Inowrocław } \\
(\mathrm{n}=415)\end{array}$ & $\begin{array}{l}\text { Wieniec-Zdrój } \\
(\mathrm{n}=205)\end{array}$ \\
\hline \multicolumn{4}{|l|}{ Age: } \\
\hline - age median in years & 60.0 & 62.0 & 61.0 \\
\hline - at post-productive age & 32.7 & 37.0 & 40.2 \\
\hline \multicolumn{4}{|l|}{ Occupational activity: } \\
\hline - working & 47.4 & 35.4 & 42.0 \\
\hline - not working: & 52.6 & 64.6 & 58.0 \\
\hline - including OAPs and retired people & 46.2 & 57.6 & 53.4 \\
\hline \multicolumn{4}{|l|}{ Aim of trip: } \\
\hline - health & 37.9 & 48.4 & 66.8 \\
\hline - recreation & 36.8 & 34.7 & 18.0 \\
\hline - tourism & 15.5 & 6.6 & - \\
\hline - weekend rest & - & - & 15.2 \\
\hline - visiting relatives/friends & 4.3 & 6.5 & - \\
\hline - business, etc. & 5.5 & 3.8 & - \\
\hline \multicolumn{4}{|l|}{ Accompanying persons: } \\
\hline - alone & 31.4 & 49.3 & 61.0 \\
\hline - family/partner & 44.5 & 30.8 & 26.3 \\
\hline - friends & 21.1 & 17.5 & 12.7 \\
\hline - other & 3.0 & 2.4 & - \\
\hline \multicolumn{4}{|l|}{ Transport: } \\
\hline- car & 79.4 & 65.9 & 89.8 \\
\hline - bus / coach & 14.2 & 11.4 & 9.3 \\
\hline- train & 4.9 & 22.5 & 0.9 \\
\hline \multicolumn{4}{|l|}{ Accommodation } \\
\hline - not staying overnight & 27.5 & 16.7 & 4.4 \\
\hline - staying overnight: & 72.5 & 83.3 & 95.6 \\
\hline - at the same sanatorium (spa facility) & 48.3 & - & 87.3 \\
\hline \multicolumn{4}{|l|}{ Frequency of visits: } \\
\hline - first time & 36.7 & - & 82.9 \\
\hline - subsequent time & 63.3 & - & 17.1 \\
\hline \multicolumn{4}{|l|}{ Wish to revisit: } \\
\hline- yes & 97.8 & 85.9 & 94.1 \\
\hline- no & 2.2 & 14.1 & 5.6 \\
\hline \multicolumn{4}{|l|}{ Area of residence: } \\
\hline - own region & 27.3 & 28.3 & 40.0 \\
\hline - neighbouring regions & 48.2 & 46.0 & 58.0 \\
\hline - farther (other) regions & 24.5 & 25.7 & 2.0 \\
\hline
\end{tabular}

Source: based on Brudnicki, Barczak, Nowicki, Markiewicz (2016), Caban (2017).

way they moved around. Spa patients usually concentrated near the spa hotels, sanatoria and balneology facilities or nearby (usually along the promenades). Spa patients were busy with a variety of compulsory classes and treatments which gravely limited their movement around the spa. On the other hand, those who came to the spa in search of recreation were not limited in this way. Thus, they were more mobile and scattered within the spa space, and their walking routes were longer. This can be illustrated by the behaviour of spa patients and other tourists in Ciechocinek (Table 6). A substantial proportion of the visitors (about one quarter) went on excursions to nearby destinations such as Torun, Lichen, Włocławek, Kruszwica, Chełmno, Biskupin, Nieszawa, Raciążek, etc. In Ciechocinek, it was observed that participation in excursions grew until about the fourth visit to the spa, but
Table 6. The distance of daily walks by spa patients and other tourists in Ciechocinek in 2007

\begin{tabular}{|l|c|c|}
\cline { 2 - 3 } \multicolumn{1}{c|}{} & Spa patients & Other tourists \\
\hline Number of respondents & 111 & 89 \\
\hline $\begin{array}{l}\text { Average distance of walks } \\
\text { in metres }\end{array}$ & 2490.8 & 2975.2 \\
\hline $\begin{array}{l}\text { Minimal declared distance } \\
\text { of walks in metres }\end{array}$ & 391.2 & 769.0 \\
\hline $\begin{array}{l}\text { Maximum declared } \\
\text { distance of walks in metres }\end{array}$ & 5016.4 & 6357.4 \\
\hline
\end{tabular}

Source: Glaza (2008).

later the guests' interest in sightseeing visibly decreased (Glaza, 2008).

Polish guests arriving in Kujawy spas came mostly from cities (ca. 95\%). Large cities with over 0.5 million 


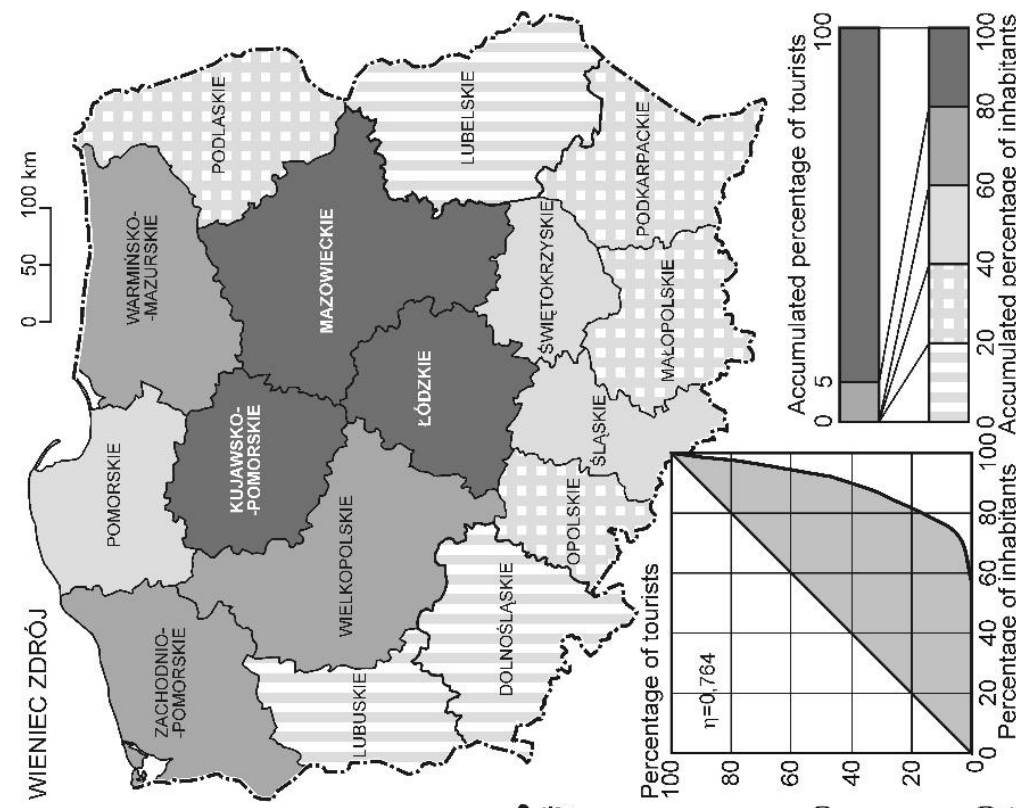

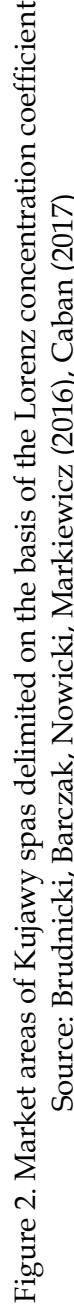

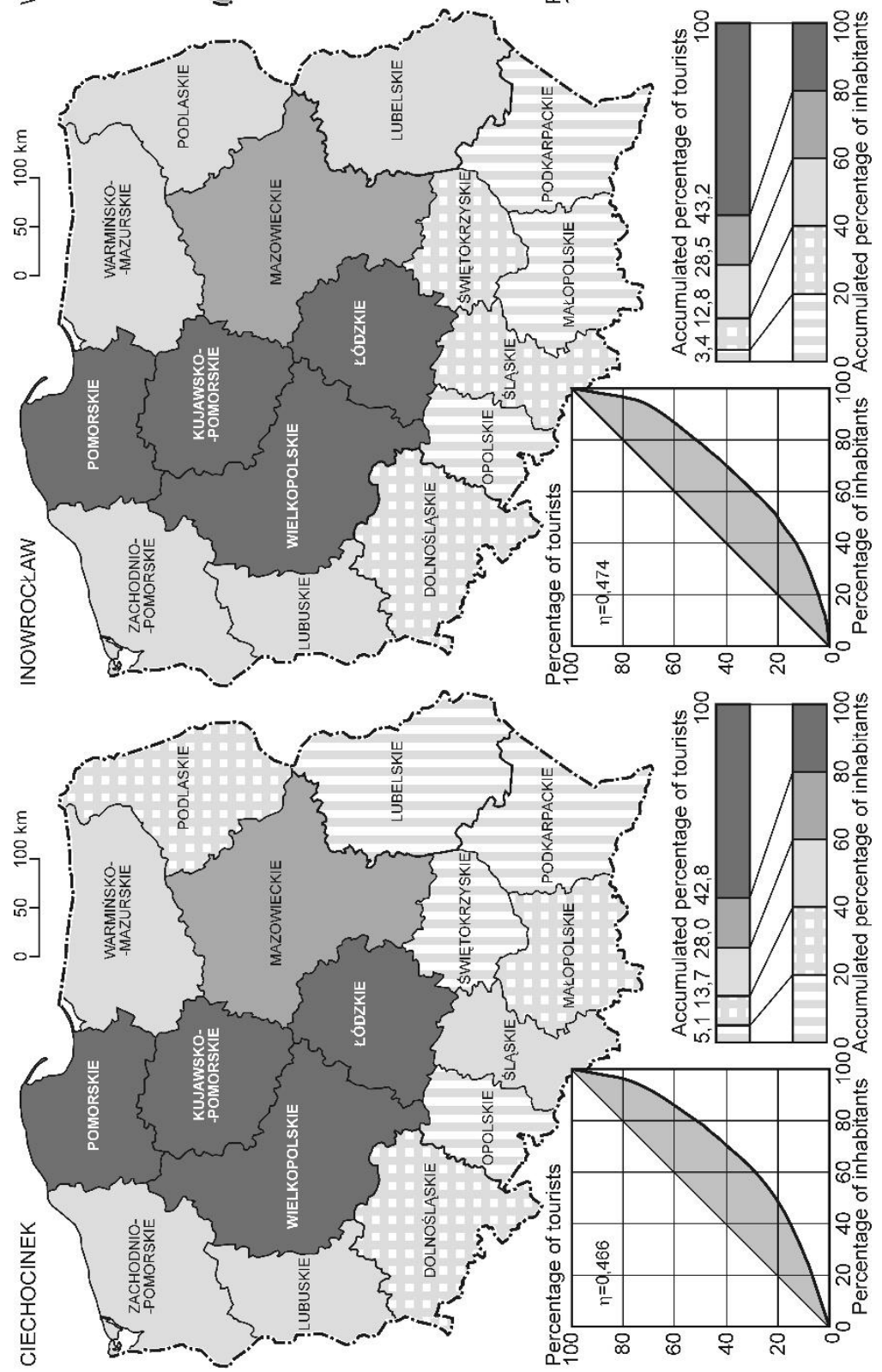


inhabitants, provided them with slightly over one third of the guests, medium-sized cities with 100-500,000 inhabitants a further third. The last third came from towns inhabited by less than 100,000 people. The proportion of guests from rural areas was marginal (not more than $5 \%$ ). Generally speaking, it could be observed that the bigger the city (the more populated), the larger the proportion of its inhabitants among the guests of Kujawy spas. They mainly served the local and regional market, within a distance of 250-300 km with over three quarters of visitors coming from that area. The proportion of areas located further away was rather insignificant on the Kujawy spa market. Respondents from places located closer to the spas (from the Kujawy-Pomeranian Province) more often came for recreational than curative reasons. On the other hand, respondents from provinces directly surrounding the Kujawy-Pomeranian region (Masovia, Łódź, Wielkopolskie, Pomeranian) as well as from those situated further from it (Silesian, Małopolskie) more often arrived for curative than other tourist reasons. A small number of visitors arriving from other provinces, located peripherally from the spas, more often declared tourist motivations than purely curative ones.

The market areas of Kujawy spas (Figure 2) were accumulated in their own and neighbouring provinces. In the case of Ciechocinek (Lorenz coefficient $\eta=0.466$ ) and Inowrocław $(\eta=0.474)$, the area populated by nearly one third of the Polish population provided over two thirds of the spa patients and other tourists. In Wieniec-Zdrój $(\eta=0.764)$, this area provided nearly all visitors. The market area analysis conducted for Ciechocinek, with visitors divided into spa-patients and other tourists, reveals small differences. The spa-patients came from a slightly larger area of Poland $(\eta=0.41)$ than other tourists $(\eta=0.47)$. Curative stays in Ciechocinek were less frequently used by the inhabitants of Wielkopolskie and Pomeranian Provinces, compared to other tourists who visited this spa in slightly larger numbers than spa patients.

\section{DISCUSSION}

The changes occurring in the tourism function in Polish spas are difficult to measure precisely. The currently available statistics lack continuity and completeness of data. Tourism statistics are based on the data concerning the use of accommodation facilities which includes those staying overnight but completely ignores one-day visitors. Statistics providing information about the capacity and use of spa facilities and categorized hotels should be treated as complete and credible, while for other tourist accommodation facilities, the data are seriously inadequate. Since 2014, data on the use of tourist accommodation has been accessible at the level of a powiat which excludes a study of tourism in individual spas. Compi- lations and estimates produced out of necessity have limited value as regards the precision of drawing conclusions regarding the scale and type of tourism. This makes it difficult to use statistical methods based on the measurement of the scale of tourism and its types and conclusions must be indirect based on indices showing positive changes taking place. The surveys conducted at different times, based partly on different sets of questions, with samples of different sizes, provide only an approximate picture of the reasons for visits to health resorts. Currently, conducting full field research at the level of individual spas is also, for various reasons, impossible. The difficulties encountered while studying changes to the tourism function in Polish spas are well illustrated by the analyses conducted in Kujawy spas.

A question arises concerning the accuracy and credibility of the conclusions presented in this article. Considering current trends (according to the indices), an apparent increase can be found in the number of spa patients as well as other tourists, with higher indices for the latter. This clearly shows that the Kujawy health resorts are turning into tourism centres. This has also been confirmed by Matczak (2019) based on an analysis of the increasing scale and variety of accommodation, in these spas. The analysis of changes to the curative and non-curative forms of tourism confirmed that the process of change varies among individual spas. It was most advanced in Ciechocinek and Wieniec-Zdrój, while in Inowrocław it began slightly later. This trend was partly confirmed in the survey which provided information about the growing advantages of the non-curative forms of tourism in Ciechocinek and Inowrocław, while in Wieniec-Zdrój spa patients still predominated. Thus, it is justified to conclude that Kujawy spas are being transformed into multifunctional tourism centres. The process is hard to measure, but the indices point to its rapid rate and intensity. Consequently, it is necessary to monitor this process because its spontaneity may lead to a growing conflict between the curative and other tourism functions, particularly in Ciechocinek.

\section{CONCLUSIONS}

Analyses of changes to the tourism function in Kujawy spas in 2000-2017 were carried out on the basis of existing academic publications and existing statistical data as well as surveys, point to the following: 1) the predominance of descriptive analyses of spas transforming into multifunctional tourism centres which use data regarding registered accommodation facilities and tourism; 2) the impossibility to directly measure the relationship between curative and other forms of tourism, due to incomplete data. Replacing this with indices provides information about the trends (direction, rate/ pace) 
of the changes occurring in the tourism function; 3 ) the number of people staying overnight at spa facilities and outside them points more clearly to changes occurring in the tourist function than the number of overnight stays; 4 ) taking full field measurements of both types of accommodation and types of tourism in health resorts, in the present socio-economic, legal and other conditions is very difficult (if it is possible at all); 5) it is necessary to continuously monitor the changes taking place in the tourism function in spas due to the possibility of conflict between the curative and other tourism functions, as well as between residential (permanent inhabitants) and tourism functions (the rapid inflow of a large number of tourists penetrating the residential areas of spas increasingly being interested in permanent settlement, e.g. in Ciechocinek). Systematically following changes to the spas' market areas improves their efficiency; 6) at present, Kujawy spas are undergoing a transformation aimed at changing them into multifunctional tourism centres. The scale of this process varies among Kujawy spas (it is most advanced in Ciechocinek and Wieniec-Zdrój, and much weaker in Inowrocław). The scale and pace of this process is determined exclusively by Polish visitors (the international character of Kujawy spas is at present virtually unnoticeable), mostly coming from their own or the neighbouring regions; 7 ) the number of spa patients and other tourists in Kujawy spas is increasing further, due to their exceptionally favourable market location, the continuing lack of real competition in neighbouring regions, the growing standard of living, the ageing society, etc., which will provoke a gradually increasing need for rehabilitation, recreation, entertainment and other services.

\section{ENDNOTES}

${ }^{1}$ The statistics present the number of accommodation users and their overnight stays at registered accommodation facilities that offered 10 or more beds. One-day stays as well as tourists staying at unregistered accommodation facilities are not included in GUS statistics. After 2014, there is no data available from the Local Data Bank, regarding Polish tourists staying at accommodation facilities in individual gminas (districts) and towns.

2 Based on Matczak (2019).

\section{BIBLIOGRAPHY}

Anszperger, A., Radkiewicz, A. (2011). Badania ruchu turystycznego w województwie kujawsko-Pomorskim w latach 2009-2010. Vol. 2. Torun: Wyd. Kujawsko-Pomorska Organizacja Turystyczna.

Butler, R.W. (1980). The concept of a tourism areas cycle of evolution: implications for the management of recourses. Canadian Geographer, 24, 5-12.
Butler, R.W. (1994). Seasonality in tourism: issues and implications. In: A.V. Seaton, C.L. Jennkins, R.C. Wood, P.U.C. Dieke, M.M. Bennett, L.R. MacLellan, R. Smith (eds.), Tourism the state of the art, (pp. 332-339). New York: Wiley.

Brudnicki, R. (2005), Uzdrowisko Inowrocław - stan aktualny i możliwości dalszego rozwoju. In: E. Rydz (ed.), Ksztaltowanie funkcji turystycznych w miejscowościach uzdrowiskowych. Tourism the state of the art, (pp. 332-339). Słupsk: Wydawnictwo Pomorskiej Akademii Pedagogicznej.

Brudnicki, R., Barczak, M., Nowicki, R., Markiewicz, P. (2016). Monitoring ruchu turystycznego w województwie kujawsko-pomorskim - 2015. Raporty z rejonów badań wykonanych dla Kujawsko-Pomorskiej Organizacji Turystycznej. Bydgoszcz: Wyższa Szkoła Gospodarki.

Buzsik, K., Jónás-Berki, M., Köbli, A., Pálfi, A. (2015). Actual trends of health tourism in Hungary: the case of Hévíz. Geographica Timisiensis, XXIV (2), 45-53.

Caban, M. (2017). Ruch turystyczny w uzdrowisku Wieniec Zdrój. Master thesis, promoter A. Matczak. Łódź: Uniwersytet Łódzki.

Cieślewicz, J., Jankowiak, D. (2012). Turystyka seksualna w Ciechocinku - próba weryfikacji miejskiej legendy. Zeszyty Naukowe Wyższej Szkoły Turystyki i Języków Obcych w Warszawie, Turystyka i Rekreacja, 9 (1), 149-162.

Durydiwka, M. (2005). Zróżnicowanie rozwoju funkcji turystyczno-rekreacyjnych w miejscowościach uzdrowiskowych. In: E. Rydz (ed.), Kształtowanie funkcji turystycznych w miejscowościach uzdrowiskowych (pp. 46-59). Słupsk: Wydawnictwo Pomorskiej Akademii Pedagogicznej.

Działalność lecznicza zakładów lecznictwa uzdrowiskowego i stacjonarnych zakładów rehabilitacji leczniczej w 2017 r. Informacje sygnalne. (2017). Kraków: Urząd Statystyczny w Krakowie, Ośrodek Statystyki Zdrowia i Ochrony Zdrowia.

Glaza, M. (2008). Zachowania przestrzenne kuracjuszy i turystów w Ciechocinku. Master thesis, promoter A. Matczak. Bydgoszcz: Uniwersytet Kazimierza Wielkiego.

Groch, J. (1991). Badania diagnostyczne uzdrowisk polskich z zastosowaniem wieloczynnikowej analizy porównawczej. Kraków: Uniwersytet Jagielloński.

Grzeszczak, S. (2014). Turystyka w Inowroctawiu w opinii kuracjuszy. Zeszyty Naukowe WSG, 23, seria: Turystyka i Rekreacja, 11, 143-149.

Jagusiewicz, A. (1998). Problemy lecznictwa i turystyki w uzdrowiskach polskich. Warszawa: Instytut Turystyki.

Jagusiewicz, A. (2006). Turystyka uzdrowiskowa. Warszawa: Instytut Turystyki.

Jędrzejewska, A. (2002). Zmiana funkcji turystycznej Ciechocinka w latach 90. XX wieku. Master thesis. Promoter S. Liszewski. Łódź: Uniwersytet Łódzki.

Joppe, M. (2010). One country's transformation to spa destination: The case of Canada [Special section]. Journal of Hospitality and Tourism Management, 17, 117-126.

Kasagranda, A., Gurňák, D. (2017). Spa and wellness tourism in Slovakia (A geographical analysis). Czech Journal of Tourism, 6 (1), 27-53.

Kowalczyk, A. (2001). Geografia turyzmu. Warszawa: Wydawnictwo Naukowe PWN.

Kowalczyk, A. (2005). Transformacja uzdrowiska w wielofunkcyjny ośrodek turystyczny - przykład Mariańskich Łaźni (Czechy). In: E. Rydz (ed.), Kształtowanie funkcji turystycznych w miejscowościach uzdrowiskowych (pp. 11-21). Słupsk: Wydawnictwo Pomorskiej Akademii Pedagogicznej.

Krasiński, Z. (2004). Cykle życia uzdrowisk: od narodzin po... Kołobrzeg: Agencja Wydawnicza Patan-Press.

Kurek, W. (ed.). (2007). Turystyka. Warszawa: Wydawnictwo Naukowe PWN. 
Lecznictwo uzdrowiskowe w Polsce w latach 2000-2010 (2011). Kraków: GUS

Łęcka, I. (2005). Uzdrowisko czy kurort? Zmiany funkcji zdrowotnych w miejscowościach uzdrowiskowych i wczasowych na świecie. In: E. Rydz (ed.), Ksztattowanie funkcji turystycznych w miejscowościach uzdrowiskowych (pp. 38-45). Słupsk: Wydawnictwo Pomorskiej Akademii Pedagogicznej.

Madeyski, A. (1997). Polskie uzdrowiska, ich charakterystyka i główne problemy. Problemy Turystyki, XX, 1-4.

Mainil, T., Eijgelaar, E., Klijs, J., Nawijn, J., Peeters, P. (2017), Research for TRAN Committee - Health tourism in the EU: a general investigation. Brussels: European Parliament, Policy Department for Structural and Cohesion Policies.

Malarz, R. (2012). Lecznicze i turystyczne funkcje uzdrowisk w Beskidzie Niskim. In: E. Rydz (ed.), Ekonomiczne i organizacyjne aspekty funkcjonowania polskich uzdrowisk (pp. 59-66). Słupsk: Wydawnictwo Naukowe Akademii Pomorskiej.

Mariot, P. (1983). Geografia cestovného ruchu. Bratislava: Veda, Vydavatelstwo Slovenskej Akademie Vied.

Matczak, A. (1992). Model badań ruchu turystycznego. Studium metodologiczne. Łódź: Wydawnictwo Uniwersytetu Łódzkiego.

Matczak, A. (2012). Funkcja uzdrowiskowa w przestrzeni Inowrocławia. In: E. Rydz (ed.), Ekonomiczne i organizacyjne aspekty funkcjonowania polskich uzdrowisk (pp. 167-181). Słupsk: Wydawnictwo Naukowe Akademii Pomorskiej.

Matczak, A. (2013). Proces przekształcania uzdrowiska w ośrodek turystyczny. Przykład Ciechocinka. In: S. Sitek (ed.), „Stare i nowe" problemy badawcze w geografii społeczno-ekonomicznej. Vol. 5 (pp. 97-115). Sosnowiec: WNoZ UŚ, PTG.

Matczak, A. (2019). Changes in the tourist function of Kujawy health resorts (based on the capacity and type of accommodation). Tourism/Turyzm, 29 (1), 53-62.

Mika, M. (2005). Możliwości rozwoju uzdrowisk Beskidu Niskiego i Bieszczad w świetle obecnych uwarunkowań. In: E. Rydz (ed.), Kształtowanie funkcji turystycznych w miejscowościach uzdrowiskowych (pp.308-317). Słupsk: Wydawnictwo Pomorskiej Akademii Pedagogicznej.

Mika, M., Ptaszycka-Jackowska, D. (2007). Formy turystyki zdrowotnej. In: W. Kurek (ed.), Turystyka (pp. 279-291). Warszawa: Wydawnictwo Naukowe PWN.

Mościbroda, J. (2005). Rozwój funkcji turystycznych i rekreacyjnych w uzdrowisku Nałęczów. In: E. Rydz (ed.), Kształtowanie funkcji turystycznych w miejscowościach uzdrowiskowych (pp. 2229). Słupsk: Wydawnictwo Pomorskiej Akademii Pedagogicznej.

Ostrowski S. (1972). Ruch turystyczny w Polsce. Warszawa.

Ptaszycka-Jackowska, D. (1999). Lecznictwo uzdrowiskowe a turystyka. Turyzm, 9, 1, 189-200.

Rajman, J., Kwiatek-Sołtys, A. (2011). Turystyka - uzdrowiska - urbanizacja. In: B. Włodarczyk (ed.), Turystyka. Księga jubileuszowa w 70. rocznice urodzin Profesora Stanistawa Liszewskiego (pp. 375-385). Łódź: Wydawnictwo Uniwersytetu Łódzkiego.

Rettinger, R. (2012). Uzdrowisko Truskawiec $w$ dobie przekształceń ustrojowych. In: E. Rydz (ed.), Ekonomiczne i organizacyjne aspekty funkcjonowania polskich uzdrowisk (pp. 195-208). Słupsk: Wydawnictwo Naukowe Akademii Pomorskiej.

Rydz, E. (ed.) (2005). Ksztaltowanie funkcji turystycznych w miejscowościach uzdrowiskowych. Słupsk: Wydawnictwo Pomorskiej Akademii Pedagogicznej.

Rydz, E. (ed.). (2012). Ekonomiczne i organizacyjne aspekty funkcjonowania polskich uzdrowisk. Słupsk: Wydawnictwo Naukowe Akademii Pomorskiej.

Rzeńca, P. (1997). Iwonicz Zdrój - przykład koegzystencji funkcji uzdrowiskowej i wypoczynkowej z innymi funkcjami miasta. Turyzm 7, 1, 73-95.
Sawińska, A. (2012). Kierunki zmian na rynku turystyki zdrowotnej na przykładzie województwa zachodniopomorskiego. In: E. Rydz (ed.), Ekonomiczne i organizacyjne aspekty funkcjonowania polskich uzdrowisk (pp. 13-20). Słupsk: Wydawnictwo Naukowe Akademii Pomorskiej.

Skonieczna, E. (2011). Funkcja turystyczna Ciechocinka. Master thesis, promoter A. Matczak. Bydgoszcz: Słupsk: Akademia Pomorska.

Szajnowska-Wysocka, A. (2011). Perspektywy rozwoju turystyki uzdrowiskowej w Polsce. In: B. Włodarczyk (ed.), Turystyka. Księga jubileuszowa w 70. rocznice urodzin Profesora Stanistawa Liszewskiego (pp. 387-401). Łódź: Wydawnictwo Uniwersytetu Łódzkiego.

Szromek, A.R. (2010). Cykliczność rozwoju uzdrowisk na przykładzie uzdrowisk polskich. In: A.R. Szromek (ed.), Uzdrowiska $i$ ich znaczenie w gospodarce turystycznej (pp. 17-40), Kraków: Proksenia.

Szromek, A.R. (2012). Funkcja uzdrowiskowa i jej znaczenie w gospodarce gmin uzdrowiskowych. In: A.R. Szromek (ed.), Uzdrowiska i ich funkcja turystyczno-lecznicza, pp. 35-58. Kraków: Proksenia.

Szromek, A.R. (2018). Changes in the activities of health resorts enterprises in the context of its business model. Zeszyty Nau kowe Politechniki Śląskiej, seria Organizacja i Zarządzanie, 127, 273-287.

Szymańska, D., Grzelak-Kostulska, E., Hołowiecka, B., Michniewicz, H. (2005). Postrzeganie miejscowości turystycznouzdrowiskowych na przykładzie Ciechocinka i Inowrocławia. In: E. Rydz (ed.), Ksztattowanie funkcji turystycznych $w$ miejscowościach uzdrowiskowych. Słupsk: Wydawnictwo Pomorskiej Akademii Pedagogicznej, 293-307.

Środa-Murawska, S. (2012). Miasta uzdrowiskowe w Polsce w ujęciu wielkości i struktury bazy obiektów zbiorowego zakwaterowania. In: E. Rydz (ed.), Ekonomiczne i organizacyjne aspekty funkcjonowania polskich uzdrowisk. Słupsk: Wydawnictwo Naukowe Akademii Pomorskiej, 21-29.

Świder, I. (2005). Hotel Villa Park w Ciechocinku jako przedstawiciel grupy markowej Polish Prestige Hotel and Resorts. Master thesis, promoter B. Włodarczyk. Łódź: Uniwersytet Łódzki.

Turystyka i wypoczynek w 1979 r. (1980). Warszawa: GUS.

Turystyka w województwie kujawsko-pomorskim w 2018 r. Informacje sygnalne (2019). Bydgoszcz: Urząd Statystyczny w Bydgoszczy.

Turystyka z lat 2001-2018 (2019). Warszawa: GUS.

Urząd Statystyczny w Bydgoszczy (2019). Turystyka w województwie kujawsko-pomorskim w 2018 r. Informacje sygnalne. Bydgoszcz: Kujawsko-Pomorski Ośrodek Badań Regionalnych.

Uzlik, R. (2004). Lázeňský cestovni ruch v Karlovarském kraji. Master thesis. Promoter A. Kowalczyk. Univerzita Karlova v Praze, Přirodovědecká fakulta, Katedra socialni geografie a regionálniho rozvoje.

Vystouil, J., Šauer, M., Bobková, M. (2017). Spa, spa tourism and wellness tourism in the Czech Republic. Czech Journal of Tourism, 6 (1), 5-26.

Widawski, K. (2017). Spa and wellness tourism in Poland - A new geographical analysis. Czech Journal of Tourism, 6 (1), 69-92.

Zajączkowski, M., Cegliński, P. (2018). Analysis of development potential of health resort enterprises on the example of Przedsiębiorstwo Uzdrowisko Ciechocinek S.A. in Aleksandrów County. Journal of Education, Health and Sport, 8 (11), 699-710.

Article received:

12 July 2019

Accepted:

14 October 2019 